\title{
The Role of the Academic and Political Empowerment of Women in Economic, Social and Managerial Empowerment: The Case of Saudi Arabia
}

\author{
Maleeha Mohammed Zaaf Al-Qahtani ${ }^{1}$, Tarek Tawfik Yousef Alkhateeb ${ }^{2,3}$, Haider Mahmood ${ }^{4, *}$, \\ Manal Abdalla Zahed Abdalla ${ }^{5}$ and Thikkryat Jebril Obaid Talalah Qaralleh ${ }^{5}$ \\ 1 College of Education, Prince Sattam bin Abdulaziz University, Al-Dilam 16213, Saudi Arabia; \\ ml.alqahtani@psau.edu.sa \\ 2 Department of Marketing, College of Business Administration, Prince Sattam bin Abdulaziz University, \\ Al-Kharj 11942, Saudi Arabia; t.alkhteeb@psau.edu.sa \\ 3 Department of Economics, Kafr Elshiekh University, Kafr Elshiekh 33511, Egypt \\ 4 Department of Finance, College of Business Administration, Prince Sattam bin Abdulaziz University, \\ Al-Kharj 11942, Saudi Arabia \\ 5 College of Education, Prince Sattam bin Abdulaziz University, Al-Kharj 11942, Saudi Arabia; \\ m.zahed@psau.edu.sa (M.A.Z.A.); e.thqraleh@yahoo.com (T.J.O.T.Q.) \\ * Correspondence: h.farooqi@psau.edu.sa; Tel.: +966-11-588-7037
}

Received: 13 April 2020; Accepted: 25 May 2020; Published: 2 June 2020

check for updates

\begin{abstract}
Women may be considered to have hidden, unutilized potential for the economy and society, if not utilized at their full capacity, i.e., with effective educational, social and political policies. Allowing women to participate fully in an economy may contribute to the sustainable development of the country in question. The empowerment of women may be accelerated if women are educated for this purpose; as a result, the political authorities in Saudi Arabia have proposed a comprehensive framework to empower women. The empowerment of women is essential in the academic sector to develop educational policies for women's capacity-building. The empowerment of women in the political process is also very important, so they can suggest appropriate policies, rules and laws that favor the empowerment of women in all sectors of the economy and society. The present research aims at testing the effects of academic and political empowerment on the economic, social and managerial empowerment of women, and opens a new horizon of debate in the practical and theoretical domain of female empowerment in Saudi Arabia. To this end, we utilized structural equation modeling due to the endogenous nature of relationships among the hypothesized variables. Perception-based data were collected on the political, academic, economic, social and managerial empowerment of women through a well-structured questionnaire. The data were collected during the period from October 2019 to January 2020 through a simple random sampling method. Then, we tested the direct effect of political empowerment, and its indirect effects through academic empowerment, on the economic, social and managerial empowerment of women. We found that political empowerment has a positive direct effect on economic and managerial empowerment, but an insignificant effect on social empowerment. Further, political empowerment has a positive direct effect on academic empowerment, which, in turn, has positive effects on economic, social and managerial female empowerment. Moreover, these indirect effects are found to be magnitudes larger than the direct effects of political empowerment. This study recommends improving the economic, social and political status of women through political and academic policies, to accelerate sustainable development.
\end{abstract}

Keywords: women's empowerment; academic empowerment; social empowerment; economic empowerment; political empowerment; managerial empowerment 
JEL Classification: J16; B55; P26

\section{Introduction}

The King Abdulaziz Center for National Dialogue (2004) discussed the four gaps in the empowerment of women, i.e., a gap in legislative rights and duties, a gap of the unutilized working-capacity of women, the educational gap in women and the social gap of women in society. This report recommended reviewing the prevailing laws related to the status of women in Saudi Arabia, to apply new strategies for formal higher education and to remove the obstacles to women acquiring legal and social positions. Moreover, various necessary government actions were suggested to improve women's participation in all practical fields of economic activities, in addition to setting up a system to protect women and their children from domestic violence.

The Arab Human Development Report (2005) highlighted the three primary deficiencies of essential human development among women, i.e., problems in acquiring knowledge, a lack of political freedoms and insufficient women's rights. These problems hinder the human development index of women throughout the Arab region. This report emphasized utilizing the full capacity of Arab women to accelerate development in all Arab countries. The report mentioned that sustainable development could not be achieved without providing rights for women. Improved education and health care for women might also activate the role of women in society. The purpose of Arab women in the traditional economy could be enhanced through greater participation in the family and community structure, in the political and liberation movements and in civil society institutions. Arab women have made a great achievement in terms of their education, mainly through their own efforts, i.e., self-education. As a result, women have obtained leadership positions, and their contributions to economic activity have increased. Arab women's rights and their participation in economic and social fields should be considered not as a luxury, but rather, as an essential component of the human rights system, as per the arguments of the International Convention on the Elimination of All Forms of Discrimination Against Women.

The Tamkeen Annual Report (2012) reviewed the national economic strategy for Bahraini female empowerment to enable them to occupy high positions in all sectors. Tamkeen was persistently developing strategies to empower the women involved in economic activities, which would help them to contribute to Bahrain's future. The report showed that Bahrain had made significant progress in the empowerment of women indicators, and had reached a high global ranking. Bahrain had the top ranking among Gulf countries concerning equal salaries for male and female labor. Bahraini women were also encouraged to enter various sectors such as wholesale and retail trade, financial services, industrial, logistics, real estate, construction and others.

The United Nations Development Programme (UNDP 2012) conducted a study in Iraq to highlight the main gaps in local and regional participation among women. The purpose was also to identify ways to increase women's participation in peacebuilding activities and economic activities. This research gave special attention to local initiatives designed to engage with and assist vulnerable groups of women, and also tried to overcome the challenges faced by local organizations in approaching these vulnerable groups. Also, this study sheds light on the reaction of people towards the economic empowerment of women. A workshop by the Iraqi Amal Association (IAA) in Erbil was conducted, and a self-assessment tool was utilized to collect information on various hurdles in to the economic empowerment of women. This research was conducted in several Iraqi governorates to gain a better understanding of a variety of issues related to the economic empowerment of women. The report floated the recommendations that Iraqi government policy and legal frameworks should address problems faced by women in local communities, with a particular focus on vulnerable women.

UNDP (2014) conducted further research on the empowerment of women in public administration. This research probed the available national data from different countries and provided analyses 
of the obstacles which hinder the participation of women and their role in the decision-making processes of public administration institutions. The report highlighted an effective approach, i.e., a minimum requirement of women's participation in public administration, especially in higher-level decision-making positions. This process would bring more women's perspectives to public policy and might involve more women in the decision-making process in public administration institutions. It would also provide a fair opportunity to women to participate in public administration.

The above discussion highlights the fact that the economic, social and managerial empowerment of women is very important for a sustainable society and economy. The political process, government policies and academic capacity would help increase the level of empowerment of women in all domains of economy and society. Therefore, this research seeks to capture the effect of the political empowerment of women on economic, social and managerial empowerment. Moreover, the political impact of the academic empowerment of women, which would develop the capacity in women to be empowered in the different domains of economic, social and managerial positions, will also be assessed.

\section{Literature Review}

There is a vast literature on the issue of empowerment of women in different contexts. First, we will discuss some international studies. For example, Wejnert (2019) claimed that market-based development would increase the levels of empowerment, literacy, maternal and general health, workforce participation and life expectancy of women. Further, participation by women in family decision-making and political awareness could help to improve political participation by women. Using population and health data, Akram (2018) investigated the empowerment of women in Pakistan and found a high level of gender discrimination, which was found to be responsible for a lower level of empowerment of women. Moreover, women's education, urbanization, property ownership by women and electronic media have helped to increase the empowerment of women. Ghosh et al. (2015) investigated the level of women's political empowerment in India and reported that a lack of education had hindered political participation by women. On the other hand, women's support-policies and education helped to raise such participation. The government allocated $33 \%$ of seats in village councils to women to improve political participation.

Kabeer (2012) argued that gender equality, the employment of women and their education can enhance economic growth and help to reduce household poverty. However, gender discrimination in the job market hinders participation by women in the workforce. Mason and Smith (2003) argued that societal indicators play a greater role in empowering women than individual indicators. The study claimed that social norms in the treatment of treating played a significant role in raising women's social status. Moreover, the age and education of women strongly influenced their level of empowerment. Setyaningsih et al. (2012) said that women's participation in small and medium enterprises (SMEs) could improve women's skills, abilities and levels of empowerment. This would also improve the health and social status of women and their roles in development in Indonesia. Varghese (2011) investigated the factors of empowerment of women in Oman, and found that women were aware of their rights and duties in society. Further, participation by women in family decisions, economic decisions, and the ability to move freely contribute to the economic and social empowerment of women in Oman.

Shirazi (2012) stated that women utilize information technology (IT) to publicly disclose discriminatory activities and laws targeting women in Iran. In 2003, 11.5 million females participated as IT users, which comprised about half of the total users in Iran. Afterward, a large number of weblogs were created to highlight the identified problems in the country, which gave momentum to the empowerment of women in Iran. Moreover, IT has helped to highlight the problems of women, religious minorities and other marginal groups in Iran, and it also facilitated the mobilization of women in achieving equal participation in the economy and society. Salhi and Golzard (2019) investigated the role of the Internet on the economic, social and political empowerment of women. The internet provides valuable information on health issues, education and general human rights. Thus, the internet 
has opened a closed society and shifted the women towards a broad global network which enhances their digital empowerment. Golzard (2019) investigated the effect of the internet on the economic empowerment of women in Tehran by collecting data through interviews. Women were found to commonly command online businesses, which positively affected their economic empowerment. The Internet has helped to market businesses run by women online, to develop business contacts and to manage the household. Low levels of computer literacy were sometimes found to be a hurdle for women be benefit from online business.

Heywood (2020) discussed the role of the radio in increasing awareness of women-related problems in Niger. Women's rights were in the country are poor because of child marriage, low literacy rates and violence against women. This study found that the radio was effective at highlighting women-related problems in society, and also that women's rights accelerated political and economic empowerment. Yasmin and Grundmann (2020) investigated the effect of the empowerment of women on cooking technology in Pakistan. Most cooking activities were performed by women, and the traditional technologies of wood and coal burning were observed mostly, which might have health consequences for the women. There was a need to switch the cooking technology toward cleaner fuel, but generally, this was not found in the investigated area. However, more educated and financially empowered women were found to be more robust in terms of choosing cleaner technology for cooking purposes.

Pieters and Klasen (2020) argue that paid employment carries gender disparity. The childcare and household responsibilities, as per social norms, were found to be hurdles to the empowerment of women. On the other hand, randomize-microfinance and business training would increase the empowerment of women. Clark et al. (2019) investigated the effect of childcare on the economic empowerment of women in Africa. Inadequate childcare facilities were shown to hinder paid-work and economic empowerment among women. Subsided childcare vouchers are provided to women, and women who are receiving labor participation vouchers showed better empowerment compared to those that that are not. However, the desire to have more children decreased with subsidized childcare, and this effect was found to be more prominent among married mothers compared to single mothers.

Hendrik (2019) investigated the effect of financial inclusion on the economic empowerment of women. The financial inclusion program gave a big push to the economic empowerment of women and also helped to reduce gender gaps. Zafarullah and Nawaz (2019) investigated the role of microfinance in employment and empowerment among women. The status of women in Bangladesh's job market was improved, particularly in the ready-made garment business. Microfinancing helped to increase the economic empowerment of women through their ability to establish small businesses in poor, rural areas. On the other hand, conservative society was a social and cultural constraint to women's entrepreneurship. Employment was also affected through harassment cases, discriminatory behavior and unpleasant working conditions. Kumar and Casey (2020) claimed that intimate partner violence (IPV) severely affected the job performance of women. Middle-class women were often found to be afraid to report IPV, as per social norms to avoid being "disgraced" in the eyes of society. This study showed that the work environment of women shifted their personalities regarding their personal lives through work achievements and access to resources. So, work improved the process of empowering of women, which also enhanced their social behavior.

Ahmed and Hyndman-Rizk (2020) found that education levels among women were increasing in Bangladesh, but that job rates were not growing at the same pace. So, the number of women with a formal education who participate in the labor market is declining, and the empowerment of women is not evolving at the desired pace. The surveyed results highlighted the fact that higher education increased the intrinsic the empowerment of women, but not instrumentally, due to limited skills among women compared to the requirements of the job market. Nassani et al. (2019) investigated the role of tourism, which was mediated by financial factors in the 24 European countries from 1990-2015. The tourism and financial sectors were shown to help promote the employment and education of women. Further, these sectors also helped to promote economic growth, which, in turn, promoted the empowerment of women. Digen et al. (2019) argue that women's competencies, management abilities 
and self-determination were very important factors in promoting women's entrepreneurship in SME businesses. This study found that the revenues were improved with the empowerment of women in business. Under the assumption of resource constraints, psychological capital was extended by the self-employment and entrepreneurship of women.

Bargain et al. (2019) argued that Arab women had contributed significantly to the demographic process of Egypt, and that this had also helped to shape the role and rights in society of women. It was found that the domestic empowerment of women had increased through health decisions, socializing and increasing expenditures, but reduced due to domestic violence. Trapaga et al. (2019) explored the empowerment of women in Mexico through a social microbusiness. This study proposed that training was needed to develop social microbusinesses. Then, these businesses could transform society in terms of developing social values which are acceptable for women, and would also empower women in productive projects. Sharma (2020) investigated the level of political empowerment among women in India. Factors which enhanced political empowerment were consciousness, support from family, the legal structure of the country, self-motivation and the political environment. Political awareness among women was found to be fundamental for political empowerment. Moreover, if the government provided a fair legal structure and political environment for both genders, then women might take up positions in the political process of the country.

The literature has also investigated the different dimensions of the empowerment of women in Saudi Arabia. Hasan (2015) studied the challenges which have occurred from past and present perspectives to explore future opportunities for the social, economic and political empowerment of women from 2015-2035. This study investigated and identified the most prominent cultural, political and economic variables which negatively affect the future of social, economic and political empowerment of women in Saudi Arabia. The study concluded that the development of the status of women was satisfactory in the social aspect, but was less so in economic and political aspects. However, a positive change was observed, i.e., that their participation in commercial stores and the medical profession was increasing. The participants of the survey were expecting progress in terms of economic and political involvement in the future. Further, inequality in gender rights, a lack of skills and political capabilities of women and weak awareness of political affairs have negatively affected women's social, economic and political participation. This study recommended legislative reforms to achieve equal rights. It was also recommended that women be given opportunities in small businesses to activate their economic role. A quota system in parliament, such as in the Shura Council and municipal councils, should be introduced to enable the political participation by women in the political and legal processes of the country.

Al-Thaqafi (2017) investigated Saudi women's entrepreneurial roles in the country's development and identified manifestations of social and cultural transformations, which could result from the economic empowerment of women. This study concluded that the economic empowerment of women should be commensurate with the pace of overall development to accelerate the developmental role of women in the country. Legislation and regulations should provide incentives to encourage participation by women in the labor market. Eastern regional developmental initiatives, e.g., the Prince Sultan Fund for Women and the Center for Business Women in the East, have the capacity to accelerate progress regarding the roles of Saudi women in the economy. This study recommended conducting annual conferences to accelerate the opportunities for women in investment and business activities.

Al-Haj and Al-Nasser (2017) claimed that glass-ceilings were barriers that prevented Saudi women from occupying higher executive positions in institutions. The level of awareness among Saudi working women in government agencies about the problem of glass-ceilings was investigated. The effectiveness of government efforts was explored to encourage women to break the glass barrier by entering leadership positions in government agencies. The problems of glass-ceilings and ignorance of the rights of women in the work environment were highlighted. The study showed that a higher level of government efforts to confront the problem would empower women to gain senior government leadership positions. It was recommended that women be trained for senior government leadership 
positions. Legislation and regulations should remove restrictions on the freedoms and movement of women within the provisions of Islamic teachings.

Rodaydah (2017) investigated the political and economic empowerment of Arab women in Jordan, Egypt, Morocco, Algeria and Saudi Arabia from 2000-2015. The study provided insights into the political and economic empowerment of Arab women by monitoring the temporal development of economic and political participation among women. This study found that a set of legal gains had been achieved to empower women in political institutions, but that these did not allow women to enter the decision-making process sufficiently. So, the participation of Arab women remained weak and restricted, and few women were included in the structures of senior management. The economic empowerment of Arab women was also found to be weak. The female participation rate in the workforce was found to be low, and the unemployment rate for women was twice that of men.

Taha and Al-Ahmadi (2017) investigated the efforts of Taibah University to empower women and spread awareness among women to participate in the academic and administrative matters of the university. The policies and procedures of the university were aimed at strengthening the empowerment of women in the light of the Kingdom's Vision 2030. The academic, economic and social obstacles to implementing the regulations were found to be a hurdle in the empowerment of women. Several measures had been initiated by the university to activate participation by women in leadership positions. But, there was still a lack of awareness among women, which was found to be an obstacle to the empowerment of women in terms of policies and procedures. This study recommends that information centers be created to inform women about available opportunities and also share the experiences of leadership among women to boost women's academic and administrative leadership capabilities.

Al-Tarawneh (2017) investigated the level of administrative empowerment and of administrative skills among Saudi women working as school administrators in the Khamis Mushayt region. Administrative empowerment was observed among school principals to a moderate degree. The study found some managerial skills in female principals, including team skills, leadership skills and decision-making skills. However, a lack of exchange of information from senior management was found to be an obstacle to the administrative empowerment of women. It is recommended that an appropriate organizational climate be created to foster the empowerment of women and provide training and development programs to develop personal skills by delegating the administrative powers to women for training purposes (Maguirre et al. 2016).

Al-Qahtani (2017) investigated the perception of male and female students of King Saud University regarding political participation by Saudi women in the Shura Council. Personal, social and political obstacles were shown to limit the political participation of women. The study observed personal obstacles to political empowerment, e.g., women being affected by their emotions and by family commitments. Social obstacles were also found to be hurdles, e.g., fear in the mind of the family and the social accountability of women exercising political roles. Moreover, political obstacles also reduce the participation of Saudi women in politics. This study recommends that women participate in the Shura Council by removing the legal and political barriers. The media should support the political participation of women and should correct related negative perceptions. Yazidi (2017) investigated the role of Saudi women in community development, as per teachings of Islamic law and the Kingdom's development plans. The role of Muslim women was confirmed to be in accordance with Islamic law. Therefore, society must be aware of the importance of the participation of women in the development and decision-making activities in society. It was found that the Saudi government was concerned about this issue, which was evident from the development plans of the Kingdom. The study recommended that pioneering models of participation in the development process of the country by Saudi women should be set as an example for female students.

Al-Omar (2018) assessed the empowerment of Saudi women in higher education institutions, and found that the rate of overall economic participation by women was weak. The rate of attendance by women in university education was found to be very low, which reduced the chances of obtaining 
higher education and academic leadership positions. The obstacles to women's leadership positions were customs, traditions, poor training and the negative attitudes of men towards women. The study recommended expanding higher education facilities for women to raise community awareness regarding the importance of administrative development among women, and for the development of society as well. Al-Qarala (2018) investigated and corroborated the positive role of Saudi universities in developing professional competencies which can empower women in the light of Vision 2030, which helped and empowered women in terms of employment. This study recommended providing financial and moral incentives for women to participate in the development of Saudi society. Leadership skills should be developed among women to empower them and to train them for leadership positions.

Youssef (2017) investigated the role of Saudi women in the Al-Kharj governorate. This study found that Saudi women there had a number of important career opportunities available, i.e., medicine, teaching, administrative and technical work, communications and women-related markets, etc. Saudi women were contributing to many social and economic activities, i.e., developing positive values among the children, contributing to family and living expenses, raising investment and savings awareness and rationalizing family consumption. But, the lack of cheap daycare facilities and of local jobs which match the available women's potential were constraints which reduced the economic contribution of women. It was recommended that a database be established for better job allocations, and to establish training and consulting centers which would accelerate the participation in the labor market.

Shouqair (2018) explored the factors which might promote leadership by Saudi women, and the developmental role of women's entrepreneurship in the Qassim region. The study found that entrepreneurial initiatives led by women were few in number due to the prevailing cultural norms and social obstacles. Saudi women were confined in these traditional areas, and were far from industrial and technical fields due to the lack of a supportive climate. Moreover, financial, social, marketing, cultural, personal and subjective obstacles were also found to be responsible for the low level of women's entrepreneurship. A low level of entrepreneurship was also found due to financial illiteracy while dealing with project budgets, and to a lack of a clear strategic vision among businesswomen. The study recommended establishing an industrial business incubator in Qassim University to support the women-owned industries at the establishment and operation stages. The private sector should be involved in partnership with universities to complete these projects, and specialized institutions should be developed to provide entrepreneurial training to the women.

Yassin (2018) investigated the impact of the empowerment of women on the financial and business market in Saudi Arabia. Developing talent among women, investing in their capabilities, enabling them to obtain appropriate opportunities and providing a safe working climate would contribute to the empowerment of women and to the sustainable development of the country. Sharabi (2019) explored the social mobility of Saudi women in Al-Kharj. This study found that the Prince Sattam Bin Abdulaziz University had played a significant role in the social mobility of Saudi women in this region by increasing the enrollment numbers of female students, which allowed women to participate in the cultural, economic and political activities. The study recommended that the university should build a strategy to achieve further social mobility for Saudi women, and should prepare society to accept the entry of women into the economic and political fields.

Al-Mallihan (2019) identified the level of empowerment of Saudi women in administrative work, and found that a prominent obstacle was male dominance. Further, limited varieties and opportunities of administrative jobs were available to women. Moreover, disapproval from the head of the family, a lower level of acceptance of society for the administrative work of women, and weak legislative structures also hindered the administrative empowerment of women. Female skills and strong legal institutions were found to be helpful in increasing the level of empowerment of women. However, men occupy a greater number of administrative positions, which prevents such positions from becoming available to women. The study recommended building the knowledge-capacity of women through training, in order to achieve the administrative empowerment in Saudi society. There 
was also a need to improve the legislation to protect women's administrative rights, in addition to effective media awareness in order to overcome the cultural and traditional obstacles to the administrative empowerment of women.

The reviewed literature highlighted the importance and hurdles facing the empowerment of women. Hence, the potential of the political and academic empowerment of women to boost economic, social and managerial empowerment has not yet been addressed in the Saudi literature. So, the present study attempted to fill this gap by conducting a survey-based study to investigate the perception of top positions in public and private institutions concerning these issues.

\section{Methods}

This research is based on a perception-based survey on the five dimensions of empowerment of women, i.e., political, academic, economic, social and managerial empowerment. Regarding perception theory, Gibson (1950) argues that any human would perceive any object in a systematic way in terms of its shape and texture etc. The environment around any human could impact the receptors and arrange an information-flow. So, perception is affected by an active approach, which allows us to observe objects from different angles. Further, the aspects and specifications of the object are arranged in perceptual array; thus, perception occurs in this way (Richards 1976). Thus, everyone has his/her own perception of a single object in the environment based on his/her own previous knowledge and/or experience. A survey could collect the opinions of respondents according to their perceptions; each respondent $\mathrm{h}$ different background knowledge and experiences. So, their perceptions will provide the ground realities of the items in the questionnaire.

A questionnaire was utilized to collect data with a Likert scale: (1) disagree (2) somewhat agree and (3) strongly agree. The questionnaire was developed, reviewed and finalized during July-September 2019. Then, the data was collected during October 2019 to January 2020 through simple random sampling. Each economic and social aspect comprises 10 items, and each managerial and academic aspect comprises 5. The political aspect comprises 3 items. Further, demographic aspects were included i.e., gender, age, experience and education. We distributed 100 questionnaires in Riyadh city and six cities in the Southern Riyadh region: Alkharj, Slayal, Bani Hotat Tamim, Dilam, Wadi Dawaser and Aflaj. Sixty-eight valid responses were received, so response the rate was $68 \%$. We could not collect more responses, as targeting higher positions is. For the analyses, we hypothesized the presence of a direct positive effect of political empowerment on the economic, social and managerial empowerment, and an indirect effect of political empowerment through academic empowerment on the economic, social and managerial empowerment. We utilized structural equation modelling to test this.

\section{Results}

Table 1 shows the demographic distribution of our respondents; $89.7 \%$ were female, showing that that we focused on females in this survey. Women know better the level of empowerment of women and women-related problems in the process of empowerment. The age distribution shows that we got responses from the age group more than 30 years; $69.1 \%$ of the respondents were in the $40-49$ age group. Experience distribution shows that we got responses from all targeted experience levels. However, most of the responses, i.e., 85.3\%, were from individuals with 10-29 years of experience. This shows that experienced respondents gave their perception, so the responses are more valid. Education distribution shows that we got responses from middle school education to $\mathrm{PhD}$ level respondents; the most responses, i.e., 58.8\%, were from individuals with a Bachelor degree. This shows that we got responses form well-educated individuals.

After discussing demographic aspects, we test the hypothesis that political empowerment (POL) has a significant positive effect on the economic empowerment of women (ECON). We further tested whether POL has a direct positive effect on ECON and an indirect effect through the academic empowerment of women (ACAD). Figure 1 and Table 2 show the hypothesized direction of these relationships. The diagnostic tests for goodness of fit are shown at the bottom of Table 2. First, Akaike 
Information Criterion (AIC) and Bayesian Information Criterion (BIC) are chosen. The Comparative Fit Index (CFI) and Tucker-Lewis Index (TLI) indices show that the values are more than 0.8 , so the hypothesized model fits well. The coefficient of determination $\left(R^{2}\right)$ is around 0.9 , and the Standardized Root Mean-Squared Residual (SRMR) is 0.08, which corroborates the goodness of fit.

Table 1. Demographic Aspects.

\begin{tabular}{|c|c|c|c|c|c|c|c|}
\hline Variable & & & & & & & \\
\hline Gender & Male & Female & & & & & \\
\hline Percentage & 10.3 & 89.7 & & & & & \\
\hline Age & $20-29$ & $30-39$ & $40-49$ & More than 50 & & & \\
\hline Percentage & 0 & 16.2 & 69.1 & 14.7 & & & \\
\hline Experience & $0-9$ & $10-19$ & $20-29$ & More than 30 & & & \\
\hline Percentage & 10.3 & 44.1 & 41.2 & 4.4 & & & \\
\hline Education & PhD & Master & Bachelor & Diploma & Higher & Middle & Primary \\
\hline Percentage & 20.6 & 16.1 & 58.8 & 1.5 & 1.5 & 1.5 & 0 \\
\hline
\end{tabular}

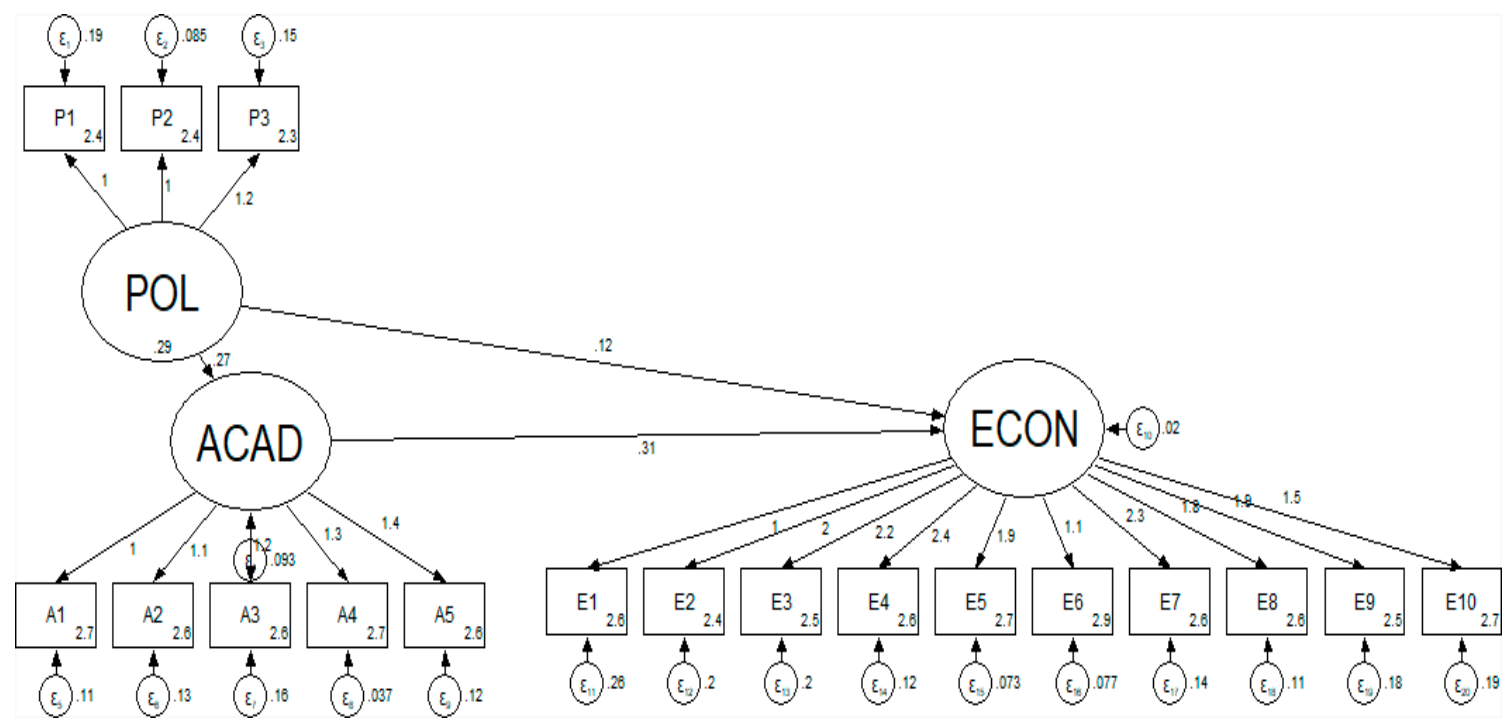

Figure 1. POL, ACAD and ECON.

After discussing the model's goodness of fit, we observed the relationships of measured variables and latent variables. The results in Table 2 show that all of the measured variables of political, academic and economic empowerment have positive and statistically significant covariance with the political, academic and economic empowerment variables. For example, the coefficients of P1<-POL, P2<-POL and P3<-POL show the positive covariance between latent variable political empowerment (POL) and its observed items P1, P2 and P3. The POL has a positive impact on P1, P2, P3. So, the latent political empowerment variable causes the respondents to give their opinion in the observed indicators P1, P2 and P3. In the same way, the coefficients of the observed items of each latent variable for ECON and SOCL show a positive association with their respective latent variables. After assessing the measurement, we tested the path analyses of the structural equation. First, political empowerment has a direct positive and statistically significant effect on economic empowerment. Political empowerment has a positive and statistically significant effect on academic empowerment, which, in turn, has a positive and statistically significant effect on economic empowerment. However, political empowerment also has a positive and statistically significant indirect effect on economic empowerment through academic empowerment. The magnitude of the indirect effect of political empowerment on economic empowerment through academic empowerment is observed to be greater than that of direct effect. However, academic empowerment is found to be helpful in increasing the effect of political empowerment on economic empowerment. 
Table 2. Economic Empowerment.

\begin{tabular}{|c|c|c|c|c|}
\hline & Coefficient & Std. Err & z-Value & $p$-Value \\
\hline \multicolumn{5}{|c|}{ Structural } \\
\hline ACAD<-POL & 0.268 & 0.089 & 3.00 & 0.003 \\
\hline $\mathrm{ECON}<-\mathrm{ACAD}$ & 0.306 & 0.124 & 2.46 & 0.014 \\
\hline $\mathrm{ECON}<-\mathrm{POL}$ & 0.121 & 0.059 & 2.03 & 0.042 \\
\hline \multicolumn{5}{|c|}{ Measurement } \\
\hline P1<-POL & 1 & & & \\
\hline Constant & 2.426 & 0.084 & 28.88 & 0.000 \\
\hline $\mathrm{P} 2<-\mathrm{POL}$ & 1.039 & 0.140 & 7.41 & 0.000 \\
\hline Constant & 2.441 & 0.076 & 32.09 & 0.000 \\
\hline P3<-POL & 1.223 & 0.170 & 7.18 & 0.000 \\
\hline Constant & 2.338 & 0.092 & 25.39 & 0.000 \\
\hline $\mathrm{A} 1<-\mathrm{ACAD}$ & 1 & & & \\
\hline Constant & 2.662 & 0.057 & 46.39 & 0.000 \\
\hline $\mathrm{A} 2<-\mathrm{ACAD}$ & 1.111 & 0.198 & 5.62 & 0.000 \\
\hline Constant & 2.617 & 0.062 & 41.89 & 0.000 \\
\hline A3-ACAD & 1.196 & 0.213 & 5.62 & 0.000 \\
\hline Constant & 2.618 & 0.069 & 37.90 & 0.000 \\
\hline $\mathrm{A} 4<-\mathrm{ACAD}$ & 1.264 & 0.186 & 6.76 & 0.000 \\
\hline Constant & 2.676 & 0.057 & 47.18 & 0.000 \\
\hline $\mathrm{A} 5<-\mathrm{ACAD}$ & 1.351 & 0.222 & 6.07 & 0.000 \\
\hline Constant & 2.588 & 0.070 & 37.13 & 0.000 \\
\hline $\mathrm{E} 1<-\mathrm{ECON}$ & 1 & & & \\
\hline Constant & 2.603 & 0.066 & 39.30 & 0.000 \\
\hline $\mathrm{E} 2<-\mathrm{ECON}$ & 1.988 & 0.693 & 2.87 & 0.004 \\
\hline Constant & 2.426 & 0.073 & 33.25 & 0.000 \\
\hline $\mathrm{E} 3<-\mathrm{ECON}$ & 2.180 & 0.756 & 2.88 & 0.004 \\
\hline Constant & 2.471 & 0.076 & 32.37 & 0.000 \\
\hline $\mathrm{E} 4<-\mathrm{ECON}$ & 2.421 & 0.798 & 3.03 & 0.002 \\
\hline Constant & 2.574 & 0.073 & 35.26 & 0.000 \\
\hline $\mathrm{E} 5<-\mathrm{ECON}$ & 1.855 & 0.620 & 2.99 & 0.003 \\
\hline Constant & 2.691 & 0.056 & 48.03 & 0.000 \\
\hline E6 $<-\mathrm{ECON}$ & 1.091 & 0.388 & 2.81 & 0.005 \\
\hline Constant & 2.853 & 0.043 & 66.43 & 0.000 \\
\hline E7<-ECON & 2.336 & 0.779 & 3.00 & 0.003 \\
\hline Constant & 2.559 & 0.073 & 34.96 & 0.000 \\
\hline E8<-ECON & 1.829 & 0.621 & 2.94 & 0.003 \\
\hline Constant & 2.574 & 0.060 & 42.91 & 0.000 \\
\hline E9<-ECON & 1.933 & 0.677 & 2.86 & 0.004 \\
\hline Constant & 2.544 & 0.070 & 36.18 & 0.000 \\
\hline E10<-ECON & 1.460 & 0.537 & 2.72 & 0.007 \\
\hline Constant & 2.691 & 0.063 & 42.53 & 0.000 \\
\hline \multicolumn{5}{|c|}{ Goodness of fit } \\
\hline AIC & 1506.866 & & & \\
\hline $\mathrm{BIC}$ & 1633.378 & & & \\
\hline CFI & 0.849 & & & \\
\hline TLI & 0.825 & & & \\
\hline $\mathrm{R}^{2}$ & 0.893 & & & \\
\hline SRMR & 0.080 & & & \\
\hline
\end{tabular}

In academic empowerment, the observed items are related to scientific production, participation in scientific events, contributions in academic institutions and participation in defining academic policies and strategies by women. More than $60 \%$ of the respondents agreed on the dimensions of academic empowerment. A small percentage disagreed and the rest agreed somewhat. Therefore, all these indicators could increase levels of academic participation among women, which could lead 
to more favorable academic policies in favor. In turn, academic empowerment could help women be economically more productive which may also increase participation by women in academic and nonacademic sectors.

In Figure 2 and Table 3, we test the hypothesis that POL has significant positive effect on social empowerment (SOCL). We further test whether POL has a direct positive effect on SOCL and an indirect effect through ACAD. First, a goodness of fit diagnostic test is presented at the bottom of Table 3. AIC and BIC were the lowest values. Moreover, the CFI and TLI indices showed values greater than $0.8, \mathrm{R}^{2}$ is around 0.9 , and SRMR is 0.071 , corroborating the goodness of fit. Now, we examine the relationships of the measured and latent variables. The results show that all measured variables (items) of political, academic and social empowerment have positive and statistically significant covariance with their respective latent political, academic and social empowerment variables. After assessing the measurement, we test the path analyses structural equation. First, political empowerment has a statistically insignificant direct effect on the social empowerment. This means that political empowerment would not help to increase social empowerment directly. However, political empowerment has a positive and statistically significant effect on academic empowerment, which, in turn, has a positive and statistically significant effect on social empowerment. However, political empowerment has a positive and statistically significant indirect effect on social empowerment through academic empowerment. This means that academic empowerment helps the political empowerment to have positive and significant effect on social empowerment.

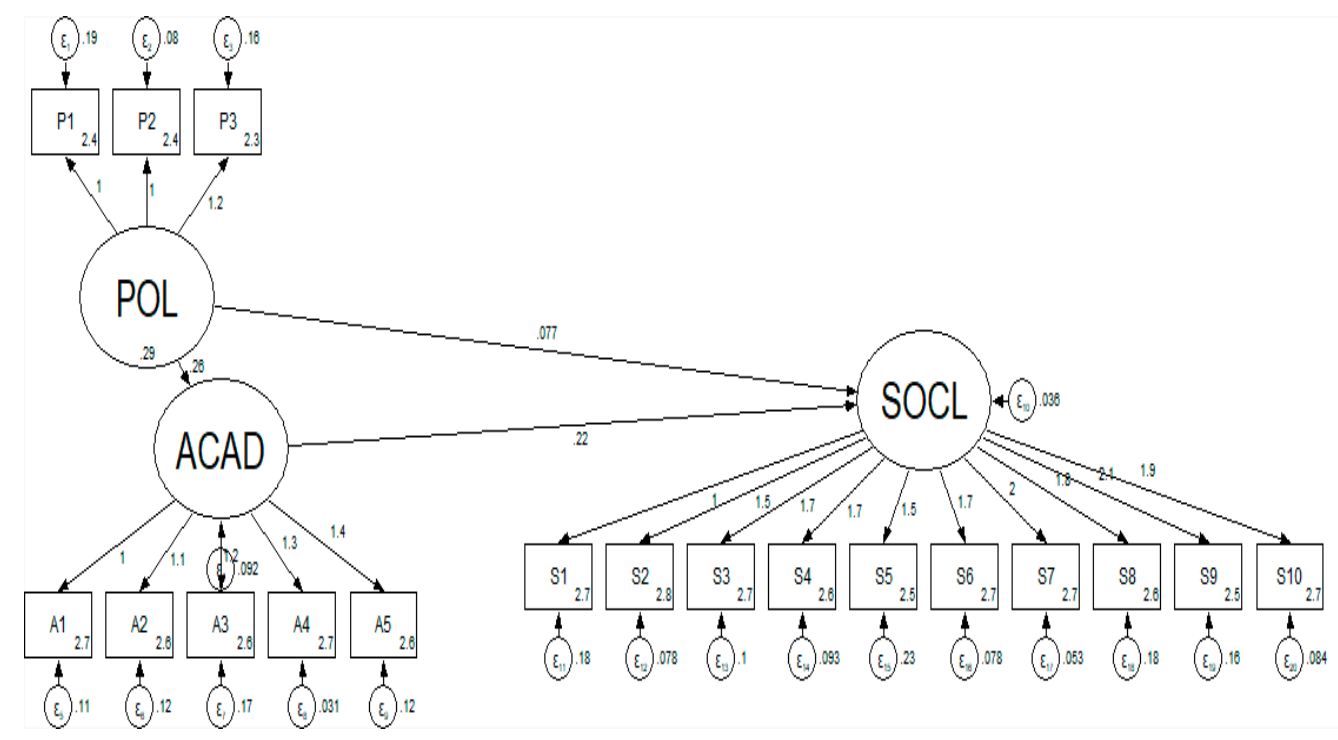

Figure 2. POL, ACAD and SOCL.

Now, we test the hypothesis that POL has a significant positive effect on managerial empowerment (MANG). We further tested whether POL has a direct positive effect on MANG and an indirect effect through ACAD. Figure 3 and Table 4 show the hypothesized direction of these relationships, and Table 4 shows the diagnostic tests of goodness of fit. AIC and BIC show values that are more than 0.8 , so the hypothesized model is a good fit. $\mathrm{R}^{2}$ is around 0.9 and SRMR is 0.074 ; this corroborates the goodness of fit of this model. We also studied the relationships of the measured and latent variables. The results showed that all measured variables of political, academic and managerial empowerment had positive and statistically significant covariance with their respective latent political, academic and managerial empowerment variables. After assessing the measurement, we tested the path analyses of the structural equation. At first, political empowerment had a direct positive and statistically significant effect on managerial empowerment. Political empowerment also had a positive and statistically significant effect on academic empowerment, which, in turn, has a positive and statistically significant effect on managerial empowerment. However, political empowerment had a positive and 
statistically significant indirect effect on economic empowerment through academic empowerment. The magnitude of the indirect effect of political empowerment on economic empowerment through academic empowerment was observed to be more than three-times greater than the direct effect. However, academic empowerment was found to be helpful in increasing the effect of political empowerment via managerial empowerment.

Table 3. Social Empowerment.

\begin{tabular}{|c|c|c|c|c|}
\hline & Coefficient & Std. Err & z-Value & $p$-Value \\
\hline \multicolumn{5}{|c|}{ Structural } \\
\hline $\mathrm{ACAD}<-\mathrm{POL}$ & 0.265 & 0.089 & 2.98 & 0.003 \\
\hline $\mathrm{SOCL}<-\mathrm{ACAD}$ & 0.223 & 0.105 & 2.12 & 0.034 \\
\hline SOCL <-POL & 0.077 & 0.059 & 1.32 & 0.187 \\
\hline \multicolumn{5}{|c|}{ Measurement } \\
\hline P1<-POL & 1 & & & \\
\hline Constant & 2.426 & 0.084 & 28.88 & 0.000 \\
\hline $\mathrm{P} 2<-\mathrm{POL}$ & 1.039 & 0.140 & 7.41 & 0.000 \\
\hline Constant & 2.441 & 0.076 & 32.09 & 0.000 \\
\hline P3<-POL & 1.223 & 0.170 & 7.18 & 0.000 \\
\hline Constant & 2.338 & 0.092 & 25.39 & 0.000 \\
\hline $\mathrm{A} 1<-\mathrm{ACAD}$ & 1 & & & \\
\hline Constant & 2.662 & 0.057 & 46.39 & 0.000 \\
\hline $\mathrm{A} 2<-\mathrm{ACAD}$ & 1.111 & 0.198 & 5.62 & 0.000 \\
\hline Constant & 2.617 & 0.062 & 41.89 & 0.000 \\
\hline A3-ACAD & 1.196 & 0.213 & 5.62 & 0.000 \\
\hline Constant & 2.618 & 0.069 & 37.90 & 0.000 \\
\hline $\mathrm{A} 4<-\mathrm{ACAD}$ & 1.264 & 0.186 & 6.76 & 0.000 \\
\hline Constant & 2.676 & 0.057 & 47.18 & 0.000 \\
\hline $\mathrm{A} 5<-\mathrm{ACAD}$ & 1.351 & 0.222 & 6.07 & 0.000 \\
\hline Constant & 2.588 & 0.070 & 37.13 & 0.000 \\
\hline $\mathrm{S} 1<-\mathrm{SOCL}$ & 1 & & & \\
\hline Constant & 2.735 & 0.057 & 47.65 & 0.000 \\
\hline $\mathrm{S} 2<-\mathrm{SOCL}$ & 1.516 & 0.411 & 3.68 & 0.000 \\
\hline Constant & 2.809 & 0.052 & 53.99 & 0.000 \\
\hline S3<-SOCL & 1.740 & 0.465 & 3.74 & 0.000 \\
\hline Constant & 2.691 & 0.060 & 45.03 & 0.000 \\
\hline $\mathrm{S} 4<-\mathrm{SOCL}$ & 1.710 & 0.459 & 3.73 & 0.000 \\
\hline Constant & 2.647 & 0.058 & 45.68 & 0.000 \\
\hline S5<-SOCL & 1.545 & 0.476 & 3.25 & 0.001 \\
\hline Constant & 2.456 & 0.070 & 34.92 & 0.000 \\
\hline S6<-SOCL & 1.716 & 0.455 & 3.77 & 0.000 \\
\hline Constant & 2.691 & 0.056 & 48.03 & 0.000 \\
\hline $\mathrm{S} 7<-\mathrm{SOCL}$ & 1.962 & 0.505 & 3.88 & 0.000 \\
\hline Constant & 2.721 & 0.058 & 46.70 & 0.000 \\
\hline $\mathrm{S} 8<-\mathrm{SOCL}$ & 1.760 & 0.503 & 3.50 & 0.000 \\
\hline Constant & 2.632 & 0.069 & 38.33 & 0.000 \\
\hline S9<-SOCL & 2.095 & 0.573 & 3.66 & 0.000 \\
\hline Constant & 2.515 & 0.074 & 34.21 & 0.000 \\
\hline S10<-SOCL & 1.854 & 0.488 & 3.80 & 0.000 \\
\hline Constant & 2.691 & 0.060 & 45.03 & 0.000 \\
\hline \multicolumn{5}{|c|}{ Goodness of fit } \\
\hline AIC & 1377.373 & & & \\
\hline $\mathrm{BIC}$ & 1503.885 & & & \\
\hline CFI & 0.864 & & & \\
\hline TLI & 0.842 & & & \\
\hline $\mathrm{R}^{2}$ & 0.892 & & & \\
\hline SRMR & 0.071 & & & \\
\hline
\end{tabular}




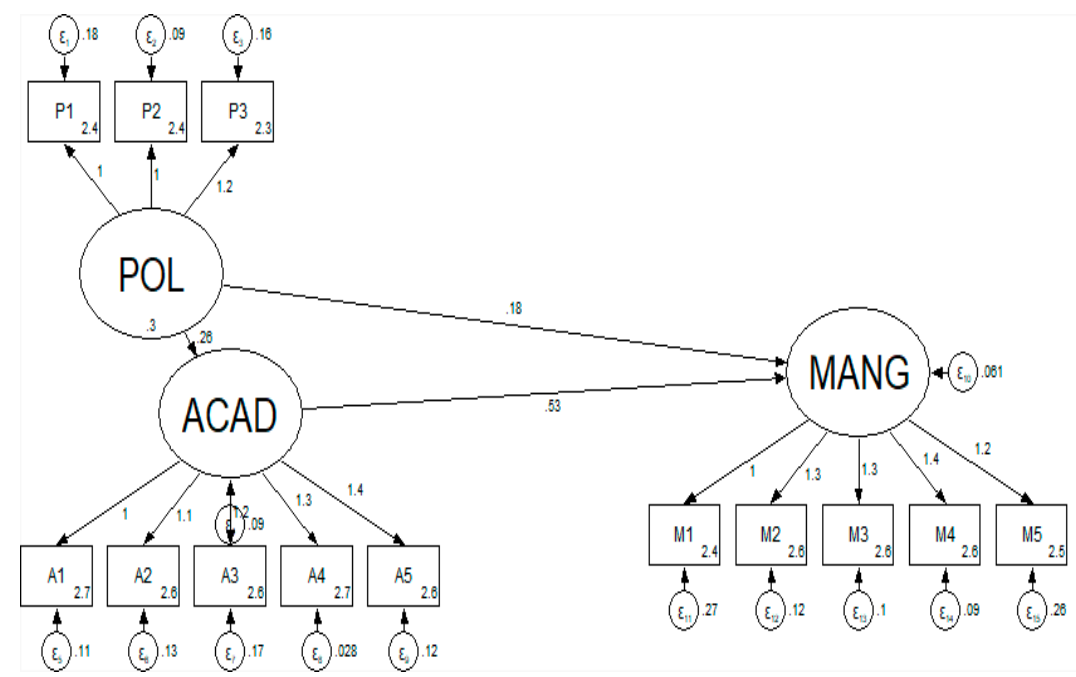

Figure 3. POL, ACAD and MANG.

Table 4. Management Empowerment.

\begin{tabular}{|c|c|c|c|c|}
\hline & Coefficient & Std. Err & z-Value & $p$-Value \\
\hline \multicolumn{5}{|c|}{ Structural } \\
\hline ACAD<-POL & 0.258 & 0.086 & 3.01 & 0.003 \\
\hline MANG $<-$ ACAD & 0.531 & 0.171 & 3.11 & 0.002 \\
\hline MANG<-POL & 0.176 & 0.087 & 2.02 & 0.043 \\
\hline \multicolumn{5}{|c|}{ Measurement } \\
\hline P1<-POL & 1 & & & \\
\hline Constant & 2.426 & 0.084 & 28.88 & 0.000 \\
\hline $\mathrm{P} 2<-\mathrm{POL}$ & 1.039 & 0.140 & 7.41 & 0.000 \\
\hline Constant & 2.441 & 0.076 & 32.09 & 0.000 \\
\hline P3<-POL & 1.223 & 0.170 & 7.18 & 0.000 \\
\hline Constant & 2.338 & 0.092 & 25.39 & 0.000 \\
\hline $\mathrm{A} 1<-\mathrm{ACAD}$ & 1 & & & \\
\hline Constant & 2.662 & 0.057 & 46.39 & 0.000 \\
\hline $\mathrm{A} 2<-\mathrm{ACAD}$ & 1.111 & 0.198 & 5.62 & 0.000 \\
\hline Constant & 2.617 & 0.062 & 41.89 & 0.000 \\
\hline A3-ACAD & 1.196 & 0.213 & 5.62 & 0.000 \\
\hline Constant & 2.618 & 0.069 & 37.90 & 0.000 \\
\hline $\mathrm{A} 4<-\mathrm{ACAD}$ & 1.264 & 0.186 & 6.76 & 0.000 \\
\hline Constant & 2.676 & 0.057 & 47.18 & 0.000 \\
\hline A5 $<-$ ACAD & 1.351 & 0.222 & 6.07 & 0.000 \\
\hline Constant & 2.588 & 0.070 & 37.13 & 0.000 \\
\hline $\mathrm{M} 1<-\mathrm{MANG}$ & 1 & & & \\
\hline Constant & 2.382 & 0.075 & 31.73 & 0.000 \\
\hline $\mathrm{M} 2<-\mathrm{MANG}$ & 1.277 & 0.282 & 4.53 & 0.000 \\
\hline Constant & 2.559 & 0.067 & 38.18 & 0.000 \\
\hline M3<-MANG & 1.327 & 0.292 & 4.55 & 0.000 \\
\hline Constant & 2.559 & 0.067 & 38.18 & 0.000 \\
\hline M4<-MANG & 1.351 & 0.302 & 4.48 & 0.000 \\
\hline Constant & 2.588 & 0.067 & 38.90 & 0.000 \\
\hline M5<-MANG & 1.197 & 0.309 & 3.87 & 0.000 \\
\hline Constant & 2.485 & 0.079 & 31.39 & 0.000 \\
\hline \multicolumn{5}{|c|}{ Goodness of fit } \\
\hline AIC & 1164.711 & & & \\
\hline BIC & 1257.930 & & & \\
\hline CFI & 0.898 & & & \\
\hline TFI & 0.872 & & & \\
\hline $\mathrm{R}^{2}$ & 0.889 & & & \\
\hline SRMR & 0.074 & & & \\
\hline
\end{tabular}




\section{Discussion}

The analyses in the previous section show that the political empowerment of women has positive effects on managerial and economic empowerment. This result is in line with the findings of Al-Mallihan (2019), i.e., that strong legal institutions were found to be helpful in raising the general the empowerment of women in Saudi Arabia. However, political empowerment does not directly affect social empowerment. On the other hand, political empowerment had a positive effect on academic empowerment in all the estimated models, and academic empowerment had positive effects on managerial, social and economic empowerment, with a larger magnitude than political empowerment. This means that political empowerment has positive indirect effects on managerial, social and economic empowerment through academic empowerment. These positive effects on all types of the empowerment are in line with the results of Kabeer (2012) and Akram (2018). These studies found a positive effect of education on the empowerment of women. Ahmed and Hyndman-Rizk (2020) found that higher education increased the intrinsic level of empowerment of women. In the case of Saudi Arabia, Al-Qarala (2018) and Sharabi (2019) found that Saudi universities were playing a role in developing professional competencies which would empower women in cultural, economic and political activities. Moreover, Al-Omar (2018) found that Saudi the rates of participation in university education among women were very low, which reduced the chances of women obtaining higher education and leadership positions. Shouqair (2018) suggested that the private business sector should encourage universities to train women for entrepreneurship which could accelerate their economic empowerment.

It is also very important to determine the major observed items in each type of empowerment. In the political empowerment, the observed items mainly consist of participation in the Shura council, political decision making, the right to vote and political leadership positions. In academic empowerment, the observed items are related to the basic concepts of scientific production, participation in scientific events, contribution in academic institutions and participation in devising academic policies and strategies. In managerial empowerment, the observed items are related to participation in policy making, strategies and decision-making by institutions, administrative positions and contributions in institutional creative and development-related activities. In the economic empowerment of women, the observed items are related to contributions in family practices, participation in investment activities, self-employment, income, entrepreneurial and business activities and ensuring food security. In social empowerment, the observed items are related to participation in family decision-making, household and children care, family counseling, contribution to social work and security, increasing both women's social value and family development.

It may be observed that the political empowerment of women can lead to defining policies and laws in favor of women to accelerate the academic, economic and managerial empowerment. But, political action may not directly affect the social status of women. In this case, the educational policies of academic institutions would raise awareness among the women to highlight their social contribution and improve their social status. Therefore, the academic empowerment of women, through academic policies and strategies, has a positive impact on all forms of empowerment. Academic empowerment may increase the capacity of women to increase their participation in all types of economic activities, so may also increase the number businesses run by women, and women's entrepreneurship and labor market participation. In the same way, education would increase the ability of women to occupy managerial positions of both public and private institutions. Hence, the political empowerment of women would suggest rules and policies that would broaden the role of women. But, academic empowerment expands raise the capacity of women, which may affect all domains of managerial, economic and social empowerment.

\section{Conclusions}

This present research investigates the direct effects of the political empowerment of women on economic, social and managerial empowerment, and the indirect effects through academic 
empowerment. For this purpose, we collected 68 valid responses of a questionnaire with a simple random sampling from Riyadh and six cities in the Southern Riyadh region. We targeted a diverse population in terms of age, education and experience to take care the all demographic classes were included in our survey and analyses. Moreover, top management, government and private sector employees were included. We used structural equation modeling to validate our hypotheses. We found that all the measured items had positive associations with their respective latent variables, i.e., the economic, social, political, academic and managerial empowerment of women.

The political empowerment of women has positive and statistically significant direct effects on economic and managerial empowerment, but these effects were found to be statistically insignificant for social empowerment. This may be assumed, because laws and government policies can be devised in the political process to activate the role of women in the economic and managerial domains. Managerial empowerment may also be increased by setting quotas for high-level jobs for women. Economic empowerment could be promoted by supporting the employment and self-employment of women through governmental financial and nonfinancial support. On the social side, the government may not deliver direct policies, but social awareness might be increased through educational policies in academic institutions. Therefore, academic empowerment has positive and statistically significant effects on the social empowerment of women, as well as on economic and managerial empowerment. Political empowerment had positive and statistically significant indirect effects on all the investigated forms of empowerment, through academic empowerment. Further, these indirect effects had larger magnitudes of coefficients among all investigated proxies for the empowerment of women than the of direct effects of political empowerment. This may be because academic participation by women may deliver policies that favor women, which could accelerate the increase in the level of participation by in all types of economic and social activities. This capacity building also enables women to obtain higher positions in institutions, and so would help to improve managerial empowerment as well. Therefore, we conclude that the political empowerment of women has a better power to boost economic, social and managerial empowerment through academic empowerment.

\section{Policy Recommendations}

Based on our results, we recommend improving the levels of participation and empowerment among women in the political process through reserving some political positions in the Shura council for women, to represent women in political decisions. Legal institutions should protect women from social pressure, which is freezing women's rights, and women should be involved in legal reforms to increase women's rights, liberties and social positions. Further, we find that the political empowerment of women through academic empowerment has a great impact on economic, social and managerial empowerment. So, there is a need to allocate some top positions in the ministry of education and in universities to women in order to increase the levels of participation by women in academia. In this way, the academic empowerment of women can trace policies to accelerate the process of women's economic, social and managerial empowerment. Academic policies should increase education levels among women, which would increase awareness among women of their legal, economic and political rights. For managerial empowerment, a quota could be implemented for top positions in the government and private organizations. This may also increase the levels of participation by women in the decision-making of institutions. Moreover, government incentives should be provided to the private sector promoting the employment and managerial positions for women in private sector business.

The government should also support women-owned businesses to increase entrepreneurship and investments by women. Concessional loans should be provided to women for entrepreneurial and business activities. Quality childcare centers should be opened, at free or subsidized lower cost, to support working mothers in their economic activities. These efforts could increase the income of women and may contribute to family welfare. Social awareness programs should be initiated in educational institutions to raise the social status of women and include women in domestic 
decisions. Furthermore, awareness should be increased among households to support women regarding participation in education, jobs, business and other economic, social and political settings. These efforts may raise the social value of women and would help them participate in economic and managerial activities. The participation of women in social-work, related to the social empowerment and security of women, should be supported by government financial and nonfinancial initiatives. Last but not least, all government and private agencies should support all types of empowerment of women and participation by women by using this hidden, unutilized potential to give a big push to the economy of Saudi Arabia and to achieve sustainable development.

\section{Limitations and Future Directions}

This study was limited by the small sample size due to targeting respondents in higher-level jobs in government and the private sector. Future studies should be conducted with a larger sample size, particularly by focusing on the women involved in SME businesses. In this way, the sample size could be significantly increased, and problems of participation by women in SME businesses could also be addressed. This process could increase the level of economic empowerment of women. Moreover, gender discrimination was not the focus of this research; addressing this issue may increase the scope of research in the future. Lastly, the role of women in poverty elevation should be focused on in future studies.

Author Contributions: Conceptualization, M.M.Z.A.-Q.; methodology, H.M.; software, H.M.; validation, T.T.Y.A.; formal analysis, M.A.Z.A.; investigation, T.J.O.T.Q., data curation, T.T.Y.A.; writing-original draft preparation, T.T.Y.A.; writing—review and editing, H.M.; supervision, M.M.Z.A.-Q.; project administration, M.M.Z.A.-Q.; funding acquisition, M.M.Z.A.-Q. All authors have read and agreed to the published version of the manuscript.

Funding: The authors extend their appreciation to the Deputyship for Research \& Innovation, Ministry of Education in Saudi Arabia for funding this research work through the project number DRI-KSU-SS-339.

Conflicts of Interest: The authors declare no conflict of interest.

\section{References}

Ahmed, Rumana, and Nelia Hyndman-Rizk. 2020. The higher education paradox: Towards improving women's empowerment, agency development and labor force participation in Bangladesh. Gender and Education 32: 447-65. [CrossRef]

Akram, Naeem. 2018. Women's empowerment in Pakistan: Its dimensions and determinants. Social Indicators Research 140: 755-75. [CrossRef]

Al-Haj, Abdulmalik, and Nouf Abdullah Al-Nasser. 2017. The working women's awareness of the problem of glass ceilings in the Saudi Arabia Kingdom: A field study on a sample of employees of the government apparatus in Riyadh. University of Sharjah Journal of Humanities and Social Sciences 15: 170-201.

Al-Mallihan, Abdullah. 2019. The extent of empowering women in administrative work in Saudi society. Al-Manara Journal for Legal and Administrative Studies 11: 77-115.

Al-Omar, Hamood. 2018. Empowering Women in higher education institutions in Saudi Arabia Kingdom: Reality and Expectation. Journal of Administrative and Economic Sciences 21: 43-63.

Al-Qahtani, Sara. 2017. The political participation of Saudi women in the Shura Council and her constraints. Journal of Social Work 58: 196-231.

Al-Qarala, Zikariat. 2018. The role of Saudi universities in developing the professional competencies necessary to empower women in the vision of 2030. Journal of the College of Arts 18: 1-20.

Al-Tarawneh, Ikhlas. 2017. Administrative empowerment and the level of the administrative skills application among Saudi women: School administrators of the Khamis Mushayt region. Hussein Bin Talal University Journal for Research 3: 35-56.

Al-Thaqafi, Khalood. 2017. The Saudi women role in development: Women entrepreneurs in the Eastern Region as a Model. King Khalid University Journal for Humanities 26: 155-77.

Bargain, Olivier, Delphine Boutin, and Hugues Champeaux. 2019. Women's political participation and intrahousehold empowerment: Evidence from the Egyptian Arab spring. Journal of Development Economics 141: 102379. [CrossRef] 
Clark, Shelley, Caroline W. Kabiru, Sonia Laszlo, and Stella Muthuri. 2019. The impact of childcare on poor urban women's economic empowerment in Africa. Demography 56: 1247-72. [CrossRef] [PubMed]

Digen, Shaun Paul, Gurjeet Kaur Sahi, Stanzin Mantok, and Pankaj C. Patel. 2019. Women's perceived empowerment in entrepreneurial efforts: The role of bricolage and psychological capital. Journal of Small Business Management 57: 206-29. [CrossRef]

Ghosh, Ratna, Paromita Chakravarti, and Kumari Mansi. 2015. Women's empowerment and education: Panchayats and women's Self-help Groups in India. Policy Futures in Education 13: 294-314. [CrossRef]

Gibson, James J. 1950. The Perception of the Visual World. Boston: Houghton Mifflin.

Golzard, Vahideh. 2019. Economic empowerment of Iranian women through the internet. Gender in Management 35: 1-18. [CrossRef]

Hasan, Hasan Mustafa. 2015. Looking for the future of social, economic and political empowerment of Saudi women. Journal of Social Work 54: 15-60.

Hendrik, Sarah. 2019. The role of financial inclusion in driving women's economic empowerment. Development in Practice 29: 1029-38. [CrossRef]

Heywood, Emma. 2020. Radio journalism and women's empowerment in Nigeria. Journalism Studies. [CrossRef]

Kabeer, Naila. 2012. Women's economic empowerment and inclusive growth: Labour markets and enterprise development. International Development Research Centre 44: 1-70.

King Abdulaziz Center for National Dialogue. 2004. Women Have Their Rights and Duties in Saudi Society. Riyadh: Department of Studies and Research.

Kumar, Smita, and Andrea Casey. 2020. Work and intimate partner violence: Powerful role of work in the empowerment process for middle-class in abusive relationship. Community Work and Family 23: 1-18. [CrossRef]

Maguirre, Mario Vazquez, Gloria Camacho Ruelas, and Consuelo Garcia de la Torre. 2016. Women's empowerment through social innovation in indigenous social enterprises. Revista de Administração Mackenzie 17: 164-90. [CrossRef]

Mason, Karen Oppenheim, and Herbert L. Smith. 2003. Women's Empowerment and Social Context: Results from five Asian Countries. Washington, DC: Gender and Development Group, World Bank.

Nassani, Abdelmohsen A., Abdullah Mohammed Aldakhil, Muhammad Moinuddin Qazi Abro, Talat Islam, and Khalid Zaman. 2019. The impact of tourism and finance on Women's empowerment. Journal of Policy Modeling 41: 234-54. [CrossRef]

Pieters, Janneke, and Stephan Klasen. 2020. Randomization for women's economic empowerment? Lessons and limitations of randomized experiments. World Development 127: 108420. [CrossRef]

Richards, Robert J. 1976. James Gibson's passive theory of perception: A rejection of the doctrine of specific nerve energies. Philosophy and Phenomenological Research 37: 218-33. [CrossRef]

Rodaydah, Yussra Saleh. 2017. The Political and Economic Empowerment of Arab Women: A Comparative Study of Jordan, Egypt, Morocco, Algeria, Saudi Arabia in the Period (2000-2015). Unpublished Master's Thesis, College of Arts, Yarmouk University, Jordan.

Salhi, Zahia Smail, and Vahideh Golzard. 2019. eWords for new worlds globalization and the empowerment of Iranian women. Middle East Journal of Culture and Communication 12: 328-47. [CrossRef]

Setyaningsih, Santi, C. P. Rucita, Ummu Hani, and Ilma Nurul Rachmania. 2012. Women's empowerment through creative industry: A case study. Procedia Economics and Finance 4: 213-22. [CrossRef]

Sharabi, Wadad. 2019. Universities and the social mobility of Saudi women, Prince Sattam University as a model. Journal of Educational and Psychological Sciences 3: 139-64.

Sharma, Eliza. 2020. Women and politics: A case of political empowerment of Indian Women. International Journal of Sociology and Social Policy. [CrossRef]

Shirazi, Farid. 2012. Information and communication technology and Women's empowerment in Iran. Telematics and Informatics 29: 45-55. [CrossRef]

Shouqair, Iman. 2018. The dimensions of enhancing the pioneering role of Saudi businesswomen, features, incentives, obstacles, empowerment policy, an applied study in the Qassim region. Journal of the Islamic University for Economic and Administrative Studies 26: 206-31. 
Taha, Muhammad, and Ayesha Al-Ahmadi. 2017. The efforts of Taibah University in the field of empowering women and the extent of awareness among them in the academies and administrations at the university. In A Research Paper Published in the Conference to Enhance the Role of Saudi Women in Community Development in Light of the Kingdom's 2030 Vision. Sakaka: Al-Jouf University in the Kingdom of Saudi Arabia, pp. 190-206.

Tamkeen Annual Report. 2012. Moving Women Forward: In Step with the Tremendous Strides Bahraini Women Have Made. Manama: Tamkeen Foundation.

The Arab Human Development Report. 2005. Towards the Rise of Women in the Arab World, Amman, Regional Office for Arab Countries. UNDP in Partnership with the Arab Fund for Economic and Social Development. Riyadh: Arab Gulf Program for United Nations Development Organizations.

Trapaga, Trápaga, Diana G, Isis Arlene Díaz-Carrión, and Sergio Cruz Hernández. 2019. Rural and indigenous Women's empowerment through productive groups and social microbusiness in Mexico. Retos-Revista de la Administracion Y Economia 9: 91-106.

UNDP. 2012. Empowering Women Economically: Integrating Women into the Iraqi Economy. Baghdad: Iraq Trust Fund. UNDP. 2014. Gender Equality and Women's empowerment in Public Administration. Beirut: Development Policies Office. Varghese, Thresiamma. 2011. Women's empowerment in Oman: A study based on Women's empowerment Index. Far-East Journal of Psychology and Business 2: 37-53.

Wejnert, Barbara. 2019. Effects of Market-Based Development on Women's Empowerment: Impact on Families. Marriage \& Family Review 55: 1-30.

Yasmin, Nazia, and Philipp Grundmann. 2020. Home-cooked energy transitions: Women's empowerment and biogas-based cooking technology in Pakistan. Energy Policy 137: 111074. [CrossRef]

Yassin, Samar. 2018. The impact of women's empowerment decisions in the Saudi Arabia Kingdom on the financial and business markets according to Vision 2030: An Applied Study on Women Workers in Saudi Institutions in Abha City. Journal of the College of Islamic and Arab Studies 4: 894-910.

Yazidi, Maha. 2017. Saudi women and their role in community development Princess Sarah bint Abdullah bin Abdulaziz Al Saud as a model. In A Research Paper Published in the Conference to Promote the Role of Saudi Women in Community Development in Light of the Kingdom's 2030 Vision. Sakaka: Al-Jouf University in the Kingdom of Saudi Arabia, pp. 190-206.

Youssef, Iman. 2017. Working women and her role in supporting the family economy in the Saudi Arabia Kingdom: An applied study on the Prince Sattam bin Abdulaziz University employees. The Scientific Journal of Trade and Finance 4: 242-76.

Zafarullah, Habib, and Faraha Nawaz. 2019. Pathways to women's empowerment in Bangladesh employment and microfinance as interventions. Asian Education and Development Studies 8: 387-404. [CrossRef] 